\title{
MFA vs. LCA, particularly as environment management methods in industry: an opinion
}

\author{
Jean-Pierre Birat ${ }^{*}$ \\ IF Steelman, Semécourt, France
}

Received: 27 September 2020 / Accepted: 6 January 2021

\begin{abstract}
MFA was born in the 1980s, independently, in various laboratories around the world. On the one hand, Industry was trying then to put numbers on its circular economy practices, while, on the other, Academia endeavored to construct a metaphor of natural ecology (BioGeoChemical Cycles [BGCC/) or of the metabolism of ecosystems to describe the activities of the anthroposphere, especially its material and the energy flows (and stocks). This article briefly reviews the early efforts of Usinor (now ArcelorMittal) in this area, in the framework of a program called "The Cycle of Iron" and points out what it was trying to achieve: basically, analyze and evaluate a true recycling rate (RR) of steel. MFA turned out to be potentially a more powerful tool than ad hoc models of materials circularity too and Industry left the leadership to academic groups to flesh out the new methodology to confront such difficult questions as the evaluation of a RR. Then the article conducts a kind of methodological and epistemological audit of the present status of MFA, positioning it in the wide framework of descriptions of material flows in space and time, and thus picturing it as a competing methodology to LCA. While the former is macro-scale, synchronic, broadly economy-oriented, the latter is micro-scale, diachronic, product and value chain-oriented, while both "report" to different communities, the Industrial Ecology community and the LCA community respectively, and more. Both schools of thoughts have been attending SAM conferences regularly, where they have been reporting their continuous search for new developments and their search for a better sustainability assessment of materials, products, industrial systems and economic activities of all kinds. The various contributions over the first 12 SAM events are analyzed. Finally, MFA and LCA are compared, feature by feature, in terms of the communities they serve and of their strengths and weaknesses. Unsurprisingly, the conclusion is that they are more complementary than competing with each other.
\end{abstract}

Keywords: LCA / MFA / management tool / industry / materials

Résumé. Comparaison de l'ACV et de l'AFM, particulièrement en tant qu'outils de gestion de l'environnement dans l'industrie : le point de vue de l'auteur. L'AFM est né au cours des années 1980, simultanément dans différents laboratoires dans le monde. D'un côté, l'industrie essayait de quantifier sa pratique de l'économie circulaire, alors que le monde universitaire s'était attelé à la construction d'une métaphore de l'écologie naturelle (cycles bio-géo-chimiques) ou du métabolisme des écosystèmes pour décrire les activités de l'anthroposphère, particulièrement en ce qui concerne les flux (et les stocks) de matériaux et d'énergie. Cet article rappelle les tentatives pionnières d'Usinor (maintenant ArcelorMittal) dans ce domaine, organisées dans le cadre d'un programme appelé le «Cycle du fer » et en identifie les objectifs : analyser et évaluer un taux de recyclage «vrai » des aciers. L'AFM s'est révélée potentiellement plus puissante que des modèles ad hoc de circularité. L'industrie a donc laissé le leadership aux groupes universitaires pour développer la nouvelle méthodologie avant de traiter de front la question d'évaluer un taux de recyclage. L'article conduit ensuite une sorte d'audit méthodologique et épistémologique sur le statut actuel de l'AFM, en le positionnant dans le contexte large de la description des flux de matière d'espace et de temps et en la décrivant comme une approche en concurrence avec l'ACV. Alors que l'AFM fonctionne à l'échelle macroscopique, est synchronique et orientée sur l'ensemble de l'économie, l'ACV fonctionne à l'échelle microscopique, est diachronique et orientée sur le cycle de vie et la chaine de valeur: les deux approches s'inscrivent dans deux communautés, respectivement celle de l'écologie industrie et celle de l'ACV. Les deux écoles de pensées fréquentent assidûment les conférences SAM,

\footnotetext{
* e-mail: jean-pierre.birat@ifsteelman.eu
} 
où elles présentent leur recherche continue de nouvelles approches pour mieux évaluer le caractère durable des matériaux, des produits, des systèmes industriels et de toutes sortes d'activités économiques. Les contributions aux 12 premières conférences annuelles successives y sont analysées. Enfin, on compare, point par point, l'AFM et l'ACV du point de vue des communautés qu'elles servent, de leurs forces et de leurs faiblesses. Sans surprise, la conclusion est que les méthodes sont complémentaires plus qu'elles ne sont concurrentes.

Mots clés : ACV / AFM / outil de pilotage / industrie / matériaux

\section{Introduction}

MFA is a young discipline, born in the 1980s, independently, in different laboratories across the world, and it solidified into a structured academic discipline in the 1990s and early 2000s. It appeared roughly at the same time as LCA, to which it is sometimes compared, something that we will do here also. Both methods share part of their methodology: they are based on mass balances applied in a carefully defined system and thus constitute an application of physics, thermodynamics, chemical or process engineering but also economics or, even more simply, accounting. As a matter of fact, one acceptation for MFA is Material Flow Accounting, while the other is Material Flow Analysis, two sister but separate disciplines.

This article was written in support of a presentation to a meeting of the SFI program in Trondheim in 2019 [1] in a session dedicated to MFA, where the author was asked to act as a discussant. Hence the oral style of the article and the focus on his own personal experience and expertise. This is an assumed impressionistic article, given as the author's opinion and not a review paper, except in as far as the author's personal publications are concerned.

The article will start from the author's personal recollection of how, at $\mathrm{Usinor}^{1}$, the team to which he belonged was confronted with specific practical problems and thus invented something that would be called MFA today, as it was initially unaware of what was being invented elsewhere. Then MFA and LCA will be compared, to point out similarities and differences in the way they picture and model the world, especially from the standpoint of environmental issues and how they are integrated in a business worldview about that topic. Comments will be given regarding the Society and Materials conferences, which were created as a consequence of the team's exploration of both worlds and their frustration at their limitations. Then the paper will focus on the connection of MFA with various user communities, especially as far as environmental issues are concerned. In the conclusions, a list of strengths and weaknesses of MFA will be proposed, from this utilitarian, i.e. business and industry-oriented standpoint.

\section{Usinor's attempt at inventing MFA}

In the late 1980s, Usinor was confronted with the need to change its raw material base from iron ore to

\footnotetext{
${ }^{1}$ Usinor became Arcelor and then ArcelorMittal through successive mergers. The research organization used to be called IRSID and then Research added to the name of company; thus, today, ArcelorMittal Research.
}

scrap $^{2}$. The need was local in Lorraine and it was an answer to the iron and steel crisis (end of the 1970s, early 1980s) based on the late reckoning ${ }^{3}$ that growth in steel production had stopped for good and that productivity in steelmaking (hours/ton) was set to jump significantly. The way to achieve this was to replace blast furnaces and oxygen converters by Electric Arc Furnaces (EAF), switching raw materials from iron ore to scrap and thus cutting energy consumption by $2 / 3$ and the workforce correspondingly. Usinor's Steel Mill in Gandrange was set to be rebuilt in this manner, in a practical example of a Schumpeter destructive transformation process. French Steel was also restructuring into a single company at the time, to privatize the activity, after a long period of protection under state custody ${ }^{4}$ [2].

Top management needed a storyline to justify this major transformation and the question to be addressed was whether enough scrap would be available, then and in the future, to justify a thoroughly new EAF steel mill to replace the Rombas integrated mill. There was thus a need to estimate the scrap resource in terms of scrap annual generation and of its connection with the recycling rate of steel.

Usinor at the time was looking at Japan for models of change. Pioneering work had been carried out there to estimate both scrap generation and the amount of scrap potentially available for recycling (cf. Fig. 1) [3].

Applying the Japanese model to the French situation seemed to indicate that only a small part of the scrap potential (30\%) was collected then and therefore that a new EAF steelshop could easily tap into this resource [4].

To flesh out these intuitions, Usinor launched a special project called the Cycle of Iron $\left(\mathrm{CdF}^{5}\right)$, to bring research on board and develop original knowledge on the scrap process route to accompany the transformation of Gandrange ${ }^{6}$ (cf. Fig. 2) [5].

One of the components of the Cycle of Iron Project was devoted to the study of the scrap resource ("explore the scrap deposit"). It was headed by Usinor's Chief

\footnotetext{
$\overline{2}$ Due to the competition between low-grade local ore (minette) and high-grade ore imported from Brazil on the one hand and to the increased availability of scrap.

${ }^{3}$ There was a long denial phase, during which society collectively thought that the production lull was temporary and that growth would pick up like before, in the 30 Glorious Years. The $6 \%$ percent growth period of the reconstruction of Europe after the second world war destructions was over.

${ }^{4}$ Usinor and Sacilor were merged into Usinor-Sacilor or $\mathrm{U}+\mathrm{S}$, to become Usinor and then changed into Arcelor and eventually ArcelorMittal.

${ }^{5}$ From the French Cycle du Fer.

${ }^{6}$ The Electric Steelmaking Shop was built in 1994. The "Cycle of Iron" project was launched officially in 1995.
} 


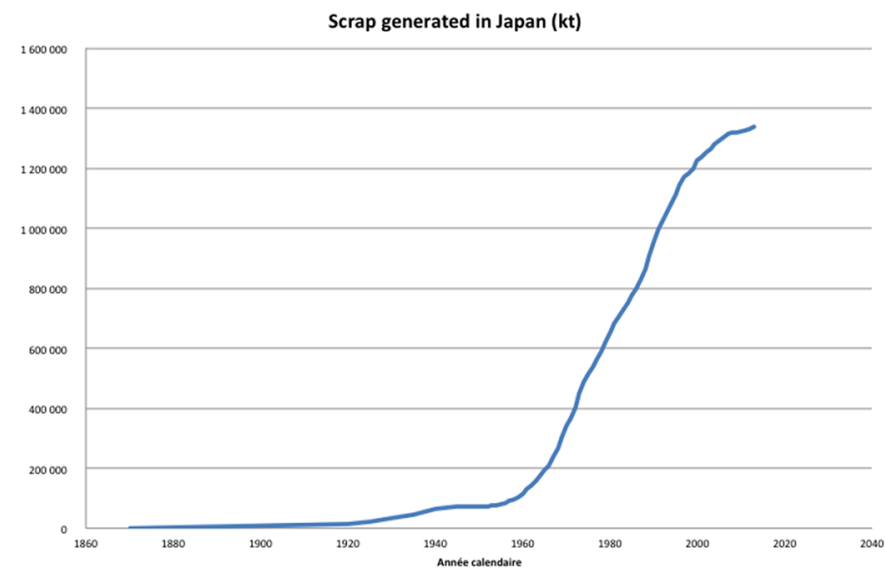

Fig. 1. Steel stock in Japan since the Meiji era (in $10^{3}$ tons).

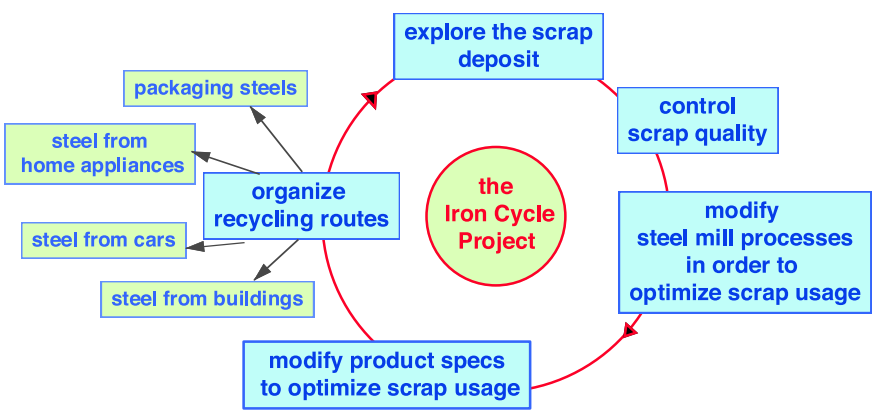

Fig. 2. Structure of the Iron Cycle project (1995-2002).

Economist, Alain Moreau, whose task was to work out a dynamic model of scrap generation, based on the timeseries of steel production. The model was a flow model, assuming that obsolete scrap (consumer scrap) would be generated at the end of life of goods, with a spread in their lifetime and provision for spare parts to help maintain the goods during their use time; scrap not collected at end of life was "lost", i.e. dissipated in the environment or lost in landfills, either regulated or wild ones. The study was never published in details, except recently [6,7], but the final outcome showed the evolution of the collecting rate of scrap from 1950 until 1990 as given in Figure 3 [5]. In the late 1960s, the collecting rate was larger than 1: this showed that scrap was indeed coming from a reservoir which released material late compared to a model of end-of-life and immediate release. This suggested that a stock and flow model needed to be built rather than a simple flow model (cf. Fig. 4).

Moreover, the study showed that the collecting rates were much higher than the $30 \%$ intuited from the initial study [4]. There was enough scrap to feed the new EAF, as the many years of operation of the steelshop demonstrated in a practical way, although not as much as first imagined.

Figure 4 shows the model that was imagined at the time. It is not fully self-coherent (scrap stock on the left means incrementation of the scrap stock by the annual collection, while scrap stock on the right means the stock incremented over the long time) as it mixes static and dynamic elements. Moreover, it connects with a concept of the anthropogenic mine, an expression not yet used at the

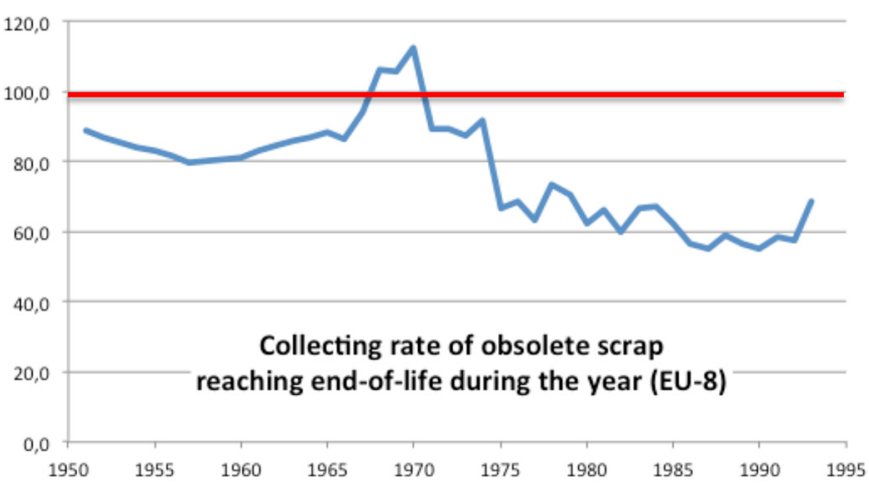

Fig. 3. Collecting rate of scrap (observed) as a function of historical time, expressed as a fraction of scrap potential actually collected as scrap ${ }^{7}$.

time. It also does not show the stock of steel in use, although the transformation from steel consumption to scrap potential, via a lifetime function, toggles between flux and stock, steel coming in and scrap going out - moreover, the transformation also changes the name of iron from steel to scrap. The CdF project stopped before this model was properly worked out.

This was the time when T. Graedel at the Yale University launched his STAFF project and the author was invited to come to the annual review meetings for the whole duration of the project - the author was one of the very few industry participants at the time. He became aware of MFA then and of its conceptual development and he surmised that the new methodology would eventually bring USINOR the answers that were needed.

At the end of this experience, there was no clear answer from MFA in terms of recycling, recycling rate and anthropogenic mines, however: when the question was raised, the answer was that the concept of recycling rate was not clear, as, indeed, many definitions could be proposed! The question was indeed felt by the MFA community as looking backwards to the past, while the field was more intent on developing foresight visions and looking at the future!

ArcelorMittal stopped doing research in that area, although it kept close to the academic work and to the expanding number of research teams active in MFA. Moreover, the demand was for the industrial researchers to get involved in LCA, a field that the team had also helped bring to life in the $1980 \mathrm{~s}$ as it seemed to hold more immediate returns for an industry like steel ${ }^{8}$.

7 The whole curve relates to the post war period. At the end of the 60 s, scrap demand grew so high (end of the 30 Glorious Years) that scrap was collected from the stock to complement the direct flow of obsolete scrap. Then steel demand dropped due to the onset of the 40 Piteous Years and, in parallel, the scrap business became industry-like, dropping the art and trade style prevalent before.

${ }^{8}$ This is probably an improper way to present the dichotomy between both methods, as the outcome of getting involved in LCA turned out to be at odds with the initial expectations. Moreover, steel as a sector ignored MFA until rather recently, while the nonferrous metals commissioned many MFA studies in between. 


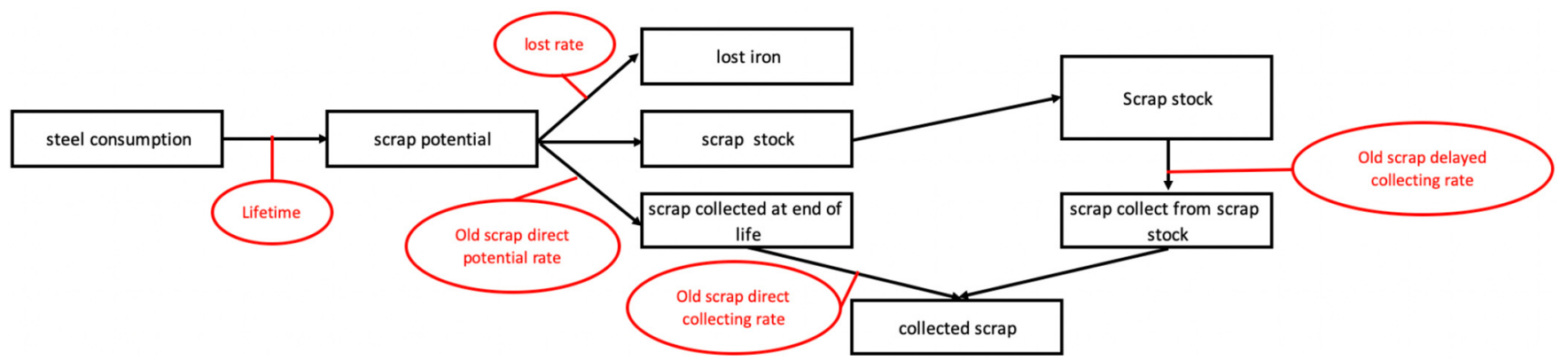

Fig. 4. Schematic stock and flow model developed as part of the CdF project.

In particular, LCA was addressing many environmental issues, contrary to MFA: the approach was related to consumer or investment goods incorporating steel, thus offering the opportunity of fleshing out the industry's green dimension organized around the products it puts on the market. Whether, with hindsight, this promise was fulfilled was another matter that ought to be explored in a different paper: the experience of the author and the evidence of the SAM conferences seem to suggest that it was only partially delivered and that LCA has been continuing on its momentum [15].

\section{LCA vs. MFA}

The similarities and differences of LCA and MFA are fairly simple to describe from a conceptual and methodological standpoint, although the way they were and are still perceived by the economic sectors ought to probably be analyzed more carefully, which will be tentatively done here.

Conceptually, MFA and LCA look at time and space (geographic and economic space) from very different standpoints (cf. Fig. 5) - so that they can be compared to the dichotomy of history/geography (Tab. 1 [8]).

Speaking first of temporality [9], LCA is focused on time, the time of the life cycle (LC) of the functional unit, of which it is telling the story. On the other hand, MFA looks at what happens hic (et nunc) during a particular year. This is what literary criticism calls, respectively, diachronic and synchronic approaches [8].

Note that LC time is different from calendar time in as far as it does not actually flow in the "LCA universe" except for the functional unit and indeed everything else, in the background in particular but also in the foreground, is (usually) not time-dependent. MFA, on the other hand, is also interested in time, as its dynamic version deals with a pile-up of annual static MFAs and various years connect together by an exchange of material to represent the generation of end-of-life waste.

Paradoxically, a fully dynamic version of LCA still remains in limbo today [10,11]: LCA is foremost a STEM approach, which does not explore the conceptual subtleties that SSH would provide, for example, the multidimensional nature of time.

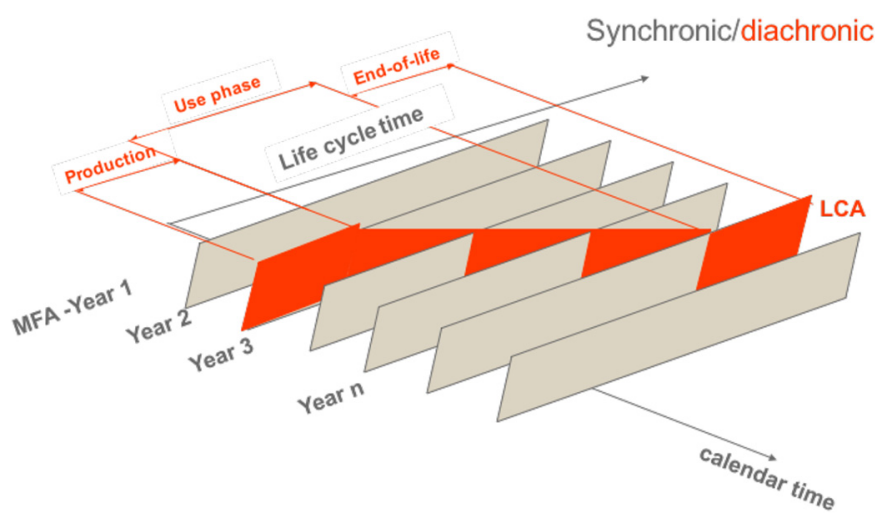

Fig. 5. Temporalities in LCA and MFA: a comparison [8].

In terms of space, LCA deals with a system, usually a small one ${ }^{9}$, which the approach isolates and follows through time. One might use the analogy of fluid dynamics and describe LCA as a Lagrangian coordinate approach: this is indeed the theoretical framework in which the mass and energy balances that form the base of LCA may be conducted to match physical principles. This functional unit is described with a large set of input and output variables that describe its relationship with the environment, in terms of energy and raw materials footprints (upstream part of environmental issues) but also of emissions and waste generation (downstream part of environmental issues): LCA is time-consuming to implement because of its complexity, which is why its conclusions are often organized in terms of middle- or end-point indicators; its final interpretation may be difficult, as weighing for example Climate Change (GHG emissions) vs. public health (toxicology) is a complex issue. Last, LCA is a micro-vision of the world, a concept common in economy.

\footnotetext{
${ }^{9}$ The topic of an LCA, the functional unit, is not necessarily small but, historically, LCA has been developed to describe the environmental footprint of consumer products that are mass produced: small functional unit but overall large economic importance. Only such systems have a large-enough impact that deserves the effort and the complexity of carrying out an LCA.
} 
Table 1. Similarities and differences between LCA and MFA.

\begin{tabular}{|c|c|c|}
\hline & LCA & MFA \\
\hline Time, temporality & $\begin{array}{l}\text { Life-cycle time but no significant } \\
\text { dynamic LCA }\end{array}$ & Static and dynamic MFA \\
\hline Scale, space & Micro-vision (the functional unit) & Macro-vision \\
\hline Reference system & $\begin{array}{l}\text { Life cycle, value chain, thus a focus on } \\
\text { products }\end{array}$ & $\begin{array}{l}\text { Large economic/geographic systems, thus a } \\
\text { focus on materials, substances or elements }\end{array}$ \\
\hline Complexity & $\begin{array}{l}\text { High! Need for commissioning a highly- } \\
\text { specialized practitioner to carry out the } \\
\text { job, time consuming (except for } \\
\text { streamlined LCA) }\end{array}$ & $\begin{array}{l}\text { Less than LCA, but difficulty of accessing } \\
\text { data }\end{array}$ \\
\hline Scope & $\begin{array}{l}\text { Covers both environmental and public } \\
\text { health spheres, informed by a wealth of } \\
\text { indicators. Need for "summarizing" } \\
\text { indicators (midpoint, endpoint). The } \\
\text { physical meaning of what LCA tracks } \\
\text { often remains hidden behind indicators. }\end{array}$ & $\begin{array}{l}\text { MFA mostly tracks mass an energy, } \\
\text { sometimes monetary values. MFAc: } \\
\text { outputs are often aggregated. MFA also } \\
\text { tracks environmental issues: raw material } \\
\text { issues upstream of the value chain and } \\
\text { waste, downstream. }\end{array}$ \\
\hline $\begin{array}{l}\text { Different level of } \\
\text { information }\end{array}$ & $\begin{array}{l}\text { LCA describes the value chain and its } \\
\text { circular economy part, which increases } \\
\text { material efficiency and cuts GHG } \\
\text { emissions. LCA is therefore a powerful } \\
\text { tool for assessing material and energy } \\
\text { savings. }\end{array}$ & $\begin{array}{l}\text { MFA focuses on raw materials (primary } \\
\text { and secondary) and thus on their } \\
\text { availability. However, some information is } \\
\text { missing, like recycling rates (steel, metals, } \\
\text { most materials), or contamination of scrap } \\
\text { (e.g. aluminum, all metals). }\end{array}$ \\
\hline Standardization & Yes & No \\
\hline Economics & $\begin{array}{l}\text { LCA deals with externalities, except } \\
\text { LCC which tries to take economic on } \\
\text { board }\end{array}$ & $\begin{array}{l}\text { MFA deals with externalities, except IOA } \\
\text { as related MFA }\end{array}$ \\
\hline Social dimension & $\begin{array}{l}\text { Social (SLCA) is not "social" in a general } \\
\text { way, but labor-rules related }\end{array}$ & $\begin{array}{l}\text { Usually, there is no Social Sciences in } \\
\text { MFA, beyond economic and geographic } \\
\text { analyses }\end{array}$ \\
\hline Related fields & $\begin{array}{l}\text { Environmental footprint, business } \\
\text { management, physics, accounting, } \\
\text { policymaking (product management), } \\
\text { public health }\end{array}$ & $\begin{array}{l}\text { Geography, foresight, strategy, } \\
\text { policymaking }\end{array}$ \\
\hline Communities & LCA community & Industrial Ecology community \\
\hline Size & Large & Medium sized \\
\hline
\end{tabular}

MFA, on the other hand, usually looks at a particular substance (e.g. phosphorus or lithium), or element (phosphorus, lithium or iron) or material (steel) and follows it through a variety of trajectories inside the anthroposphere, or, less often, inside anthroposphere, biosphere and geosphere. There are variants that look at energy (EFA).. and it would be nice to have one looking at exergy ( $\mathrm{E}_{\mathrm{x}} \mathrm{FA}$ ?). MFA is a macro-vision of the world.

LCA is usually understood as product-oriented and this resonates within businesses, which are focused on growing markets and market share. The environmental dimension is also important, in as far as LCA proposes a methodology to take the environment on board, where economics or traditional business practice would be at odds with integrating in their strategy what they consider as externalities. Many businesses have LCA teams which are looking for ways of using LCA beyond the marketing targets of the early adoption of LCA. Worldsteel has developed an LCI database for steel, mainly because it felt that "good data" was essential for the sector. The LCA community is huge, comprising academic and industrial teams as well as countless practitioners organized as consultants. Several high-visibility journals are published in connection with LCA and many general ones publish LCA studies. There are not many institutions bringing together the MFA community, like SETAC or EPLCA do for LCA [12], if one dismisses the ISIE as more general [13]. Moreover, LCA is standardized at ISO level, a rather unique case for a scientific discipline: didactic presentations of LCA usually refer to these ISO standards. LCA describes a life-cycle, therefore the value-chain that makes and uses the functional unit: it is thus fully embedded in the economic fabric. As mentioned before, LCA is more oriented towards the past than the future, but many researchers would disagree with this statement.

The MFA community belongs to the larger community of Industrial Ecology, which is why MFA is often described as the study of study of anthropospheric metabolism or socio-economic metabolism. The MFA community is smaller than the LCA community. 


\section{Box 1 \\ MFA in the SAM conferences according to [15].}

MFA has been the other major tool/discipline, which has been central to the SOVAMAT/SAM initiative: it was at the core of seven sessions. It is sometimes seen as a competitor to LCA methods. However, MFA is actually a completely different approach, focusing on a macro-vision of the world contrary to the micro-vision of LCA. It is closer to geography in terms of spatial scale, to geopolitics, strategy and foresight-prospective in terms of both spatial and temporality scales. Regarding materials, where large stocks are accumulated "in-use" (LiU, Life in Use) in society, it is a language of choice to project materials intensity in the middle and long term and to address contemporary issues like mega-cities. Time is an essential feature of MFA, and, therefore, the discipline has developed a "dynamic MFA" school and has been recognized as a powerful means of dealing with recycling and for coming up with reliable estimates of recycling rates. The MFA community is smaller than the LCA community but it has been proposing important and original contributions regularly in SAM seminars.

Industry is less present there than academia. The same is true of policymakers, except in the field of Material Flow Accounting, which is slightly different from $\mathrm{MFA}_{\mathrm{n}}$ (Analysis). There is no standardization of $\mathrm{MFA}_{\mathrm{c}}$, which allows a diversity of approaches but makes comparing different studies difficult. Contrary to LCA databases, MFA databases are few and organized at the level of individual publications [14]. The reference journal for MFA is the Journal of Industrial Ecology. The MFA literature does not deal comprehensively with the issues that attracted my applied research team to the field, i.e. estimates of recycling rates and of the features of the anthropogenic mine. MFAs have been widely developed for many rare and critical elements. Within the MFA field, a lot of attention is given to the upstream part of environmental issues. As mentioned before, MFA is more oriented to the future than to the past and therefore is an ideal tool for substantiating foresight studies, such as strategic explorations of broad issues like the future availability of critical materials, the future extent of the circular economy, strategies to fight or accommodate climate change, etc. On the other hand, the granularity of the environmental issues MFA tackles is coarser than LCA's, at least for the time being.

\section{Society and materials conferences}

In the early 2000s, we were convinced at ArcelorMittal that LCA and MFA should not develop independently in their own silos, which is why we created a series of
Box 2

Advances in MFA, SFA (Substance Flow Analysis) and EFA (Element Flow Analysis) according to [15]. Numbers refer to specific papers, for example 2.3 means paper 3 in SAM-2.

- Development of a large set of MFA studies, covering a broad range of materials and substances, especially in the wake of the EU interest on strategic materials $(1.14,1.16,1.18,1.19,1.20,1.21,1.22,2.2,2.8,2.9$, $3.4,3.5,3.6,3.7,3.8 ; 3.10,3.11,3.29,4.21,5.13,5.14$, $6.13,6.14,6.15,7.7,7.8,7.9,8.14,8.15,8.16,8.18$, $8.41,8.47)$.

- Connection with economics, especially with data collection through the input/output matrix methodology, in its classical and environmental versions $(1.22,2.6,3.8,3.11,6.13,7.8,7.11,8.16)$.

- Time-dependent and dynamic MFA (2.6, 2.7, 3.9, $3.10,4.21,6.15,7.9,7.11)$.

- Nuts and bolts issues related to data quality, data reconciliation and specialized software, like in the case of LCA $(1.16,1.20,8.47)$.

- An emphasis on stocks rather than flows, especially when it was proposed to shift the connection between economy and material intensity analysis (IoU) to a correlation between GDP and material stocks from one simply between GDP and material flows - which gives a completely new perspective on foresight relative to material production in the long time $(1.15,2.7,2.9,3.1,3.7,3.8,4.21,6.13)$.

- A timid connection with the Material Flow Accounting community, for example in the use of the TMR indicator (Total Material Requirement), which adds up all materials' requirements in tons at the scale of a country or a region. The two communities do not intersect much.

- Use of MFA as a tool for strategy and policymaking $(1.14,2.2,2.4,3.4,4.18,4.20,5.14,6.23,6.28$, cf. also 2 items before). In this domain, it is actually competing with LCA, which has also extended its ambition to large-scale systems. MFA was even proposed as the major tool to become the "new metrics" (2.4).

conferences, which have been bringing together representatives of both communities, the Society and Materials (SAM), conferences $[15,16]$. The underlying assumption was that neither LCA nor MFA were sufficient to address the complexity of the non-economic and non-technical issues related to materials (and other commodities, like energy, electricity, water, etc. and functions like mobility/ transport, shelter/construction/infrastructure, etc.): hence the introduction of the word "Society" in the conference title and of the concept of value of materials as its guiding light [17]. 


\begin{tabular}{|c|c|c|c|c|c|c|c|c|c|c|c|c|c|c|c|c|c|c|}
\hline \multicolumn{19}{|c|}{ Global Level } \\
\hline & 1 & 2 & 3 & 4 & 5 & 6 & 7 & 8 & 9 & 10 & 11 & 12 & 13 & 14 & 15 & 16 & 17 & \multirow{2}{*}{$\begin{array}{c}18 \\
2 \\
\mathrm{He}\end{array}$} \\
\hline $\mid$ & $\begin{array}{l}1 \\
H\end{array}$ & & & \multicolumn{5}{|c|}{ Static Cycle Available } & \multicolumn{9}{|c|}{ Dynamic Cycle Available } & \\
\hline 2 & $\stackrel{3}{\mathrm{Li}}$ & $\begin{array}{c}4 \\
\mathrm{Be}\end{array}$ & & & & & & & & & & & $\begin{array}{l}5 \\
\text { B }\end{array}$ & $\begin{array}{l}6 \\
C\end{array}$ & ${ }^{147} 7$ & $\begin{array}{l}8 \\
0\end{array}$ & 9 & $\begin{array}{l}10 \\
\mathrm{Ne}\end{array}$ \\
\hline 3 & $\begin{array}{l}11 \\
\mathrm{Na}\end{array}$ & $\begin{array}{c}12 \\
\mathrm{Mg}\end{array}$ & & & & & & & & & & & Al & $\begin{array}{l}14 \\
\mathrm{Si}\end{array}$ & $\begin{array}{c}15 \\
P\end{array}$ & $\begin{array}{c}16 \\
S\end{array}$ & $\begin{array}{l}17 \\
\mathrm{Cl}\end{array}$ & $\begin{array}{l}18 \\
\mathrm{Ar}\end{array}$ \\
\hline 4 & $\begin{array}{l}19 \\
\mathrm{~K}\end{array}$ & $\begin{array}{l}20 \\
\mathrm{Ca}\end{array}$ & $\begin{array}{l}21 \\
\text { Sc }\end{array}$ & $\begin{array}{l}22 \\
\mathrm{Ti}\end{array}$ & $\frac{23}{v}$ & ${ }^{24} \mathrm{Cr}$ & $\begin{array}{l}25 \\
M n\end{array}$ & $\begin{array}{l}{ }^{5} / 26 \\
\mathrm{Fe}\end{array}$ & $\begin{array}{l}27 \\
\text { Co }\end{array}$ & $\begin{array}{l}28 \\
\mathrm{Ni}\end{array}$ & $\begin{array}{l}29 \\
\mathrm{Cu}\end{array}$ & $\begin{array}{l}{ }^{2} 30 \\
\mathrm{Zn}\end{array}$ & $\begin{array}{l}31 \\
\text { Ga }\end{array}$ & $\begin{array}{l}32 \\
\mathrm{Ge}\end{array}$ & $\begin{array}{l}33 \\
\text { As }\end{array}$ & $\begin{array}{l}34 \\
\text { Se }\end{array}$ & $\begin{array}{l}35 \\
\mathrm{Br}\end{array}$ & $\begin{array}{l}36 \\
\mathrm{Kr}\end{array}$ \\
\hline 5 & $\begin{array}{l}37 \\
\mathrm{Rb}\end{array}$ & $\begin{array}{l}38 \\
\mathrm{Sr}\end{array}$ & $\begin{array}{l}39 \\
Y\end{array}$ & $\begin{array}{l}40 \\
\mathrm{Zr}\end{array}$ & $\begin{array}{l}41 \\
\text { Nb }\end{array}$ & $\begin{array}{l}42 \\
\text { Mo }\end{array}$ & $\begin{array}{l}43 \\
\text { Tc }\end{array}$ & $\begin{array}{l}44 \\
\mathrm{Ru}\end{array}$ & $\begin{array}{l}45 \\
R h\end{array}$ & $\begin{array}{l}46 \\
\text { Pd }\end{array}$ & $\begin{array}{l}47 \\
\mathrm{Ag}\end{array}$ & $\begin{array}{l}48 \\
\mathrm{Cd}\end{array}$ & $\begin{array}{l}49 \\
\text { In }\end{array}$ & $\begin{array}{l}50 \\
\text { Sn }\end{array}$ & $\begin{array}{l}51 \\
\mathrm{Sb}\end{array}$ & $\begin{array}{l}52 \\
\text { Te }\end{array}$ & $\begin{array}{c}53 \\
1\end{array}$ & $\begin{array}{l}54 \\
X \mathrm{e}\end{array}$ \\
\hline 6 & $\begin{array}{l}55 \\
\text { Cs }\end{array}$ & $\begin{array}{l}56 \\
\mathrm{Ba}\end{array}$ & $57-71$ & $\begin{array}{l}72 \\
\mathrm{Hf}\end{array}$ & $\begin{array}{l}73 \\
\mathrm{Ta}\end{array}$ & $\begin{array}{l}74 \\
W\end{array}$ & $\begin{array}{l}75 \\
R e\end{array}$ & $\begin{array}{l}76 \\
\text { Os }\end{array}$ & $\begin{array}{l}77 \\
\text { Ir }\end{array}$ & $\begin{array}{l}78 \\
\text { Pt }\end{array}$ & $\begin{array}{l}79 \\
\text { Au }\end{array}$ & $\begin{array}{l}80 \\
\mathrm{Hg}\end{array}$ & $\begin{array}{l}81 \\
\mathrm{TI}\end{array}$ & $\begin{array}{l}82 \\
\mathrm{~Pb}\end{array}$ & $\begin{array}{l}83 \\
\mathrm{Bi}\end{array}$ & $\begin{array}{l}84 \\
\text { Po }\end{array}$ & $\begin{array}{l}85 \\
\text { At }\end{array}$ & $\begin{array}{l}86 \\
\mathrm{Rn}\end{array}$ \\
\hline 7 & $\begin{array}{l}87 \\
\mathrm{Fr}\end{array}$ & $\begin{array}{l}88 \\
\mathrm{Ra}\end{array}$ & 89-103 & $\begin{array}{c}104 \\
\mathrm{Rf}\end{array}$ & $\begin{array}{c}105 \\
\mathrm{Db}\end{array}$ & $\begin{array}{c}106 \\
\mathrm{Sg}\end{array}$ & $\begin{array}{c}107 \\
\mathrm{Bh}\end{array}$ & $\begin{array}{l}108 \\
\mathrm{Hs}\end{array}$ & $\begin{array}{c}109 \\
\text { Mt }\end{array}$ & $\begin{array}{l}110 \\
\text { Ds }\end{array}$ & $\begin{array}{l}111 \\
\mathrm{Rg}\end{array}$ & $\begin{array}{l}112 \\
\text { Uub }\end{array}$ & $\begin{array}{l}113 \\
\text { Uut }\end{array}$ & $\begin{array}{l}114 \\
\text { Uuq }\end{array}$ & $\begin{array}{l}115 \\
\text { Uup }\end{array}$ & $\begin{array}{l}116 \\
\text { Uuh }\end{array}$ & $\begin{array}{l}117 \\
\text { Uus }\end{array}$ & $\begin{array}{l}118 \\
\text { Uuo }\end{array}$ \\
\hline & & $\begin{array}{l}\text { Lant } \\
\text { Serie }\end{array}$ & inide & 57 & 58 & 59 & 60 & 61 & 62 & 63 & 64 & 65 & 66 & 67 & 68 & 69 & 70 & 71 \\
\hline & & $\begin{array}{l}\text { Actin } \\
\text { Serie }\end{array}$ & & $\begin{array}{l}89 \\
\mathrm{Ac}\end{array}$ & $\begin{array}{l}90 \\
\text { Th }\end{array}$ & $\begin{array}{l}91 \\
\mathrm{~Pa}\end{array}$ & $\begin{array}{l}92 \\
\mathrm{U}\end{array}$ & $\begin{array}{l}93 \\
\mathrm{~Np}\end{array}$ & $\begin{array}{l}94 \\
\mathrm{Pu}\end{array}$ & $\begin{array}{c}95 \\
\text { Am }\end{array}$ & $\begin{array}{l}96 \\
\mathrm{Cm}\end{array}$ & $\begin{array}{l}97 \\
B k\end{array}$ & $\begin{array}{l}98 \\
\mathrm{Cf}\end{array}$ & $\begin{array}{l}99 \\
\text { Es }\end{array}$ & $\begin{array}{l}100 \\
\mathrm{Fm}\end{array}$ & $\begin{array}{l}101 \\
\text { Md }\end{array}$ & $\begin{array}{l}102 \\
\text { No }\end{array}$ & $\begin{array}{c}103 \\
\text { Lr }\end{array}$ \\
\hline
\end{tabular}

Fig. 6. Elements for which global cycles were derived in 2011 [18].

The conference was meant to create a forum for researchers to explore and experiment with new concepts in the nexus of materials and society and to give a chance to alternative methodologies, besides LCA and MFA, to emerge, what were called the new metrics. One clear conclusion now is that no other holistic methodology, capable of competing with LCA or MFA, emerged. This also means that both methods will endure and continue to adapt to new demands in the area.

Among the 471 papers presented during 12 SAM conferences, $15 \%$ were devoted to MFA.

Box 1 summarizes the features of MFA that they highlight.

The major innovation themes discussed in SAM meetings are given in Box 2.

A first conclusion point is the systematic exploration of the Mendeleev table achieved in terms of global flows (cf. Fig. 6): note that the coverage of the table was far from complete in 2011 (more work has been carried out since) and that dynamic MFAs were a minority. The second most important point is the use of stocks to derive foresight projections of future material use, mostly developed by Müller et al. The connection with the economics community through the input-output methodology (Leontiev matrices) is also significant, when the importance of establishing bridges between various scientific disciplines has been stressed in SAM meetings. Closer connections with $\mathrm{MFA}_{\mathrm{c}}$ are also a strong trend, as MFA helps look at the environmental footprint of materials-related activities, such as the amount of waste generated by mining.
In conclusion, SAM conferences have been acting as methodological whistle blowers, pointing to new developments and new concepts before they became mainstream production in the high impact-factor literature. This has been true, in particular, for MFA progress.

\section{MFA and various user communities}

Who is active and who is interested in MFA?:

- first of all, academics working in the field. The initial investment in modeling tools, modeling "tours de main" and background databases is such that the teams specializing in MFA have a kind of economic rent, which constitutes a barrier to entry for newcomers in the field, especially since application software and databases are rare. This gives a flavor of activism to the field. And a tendency or a risk of "siloing"...

- industry, at the level of individual companies, is only weakly involved. Usinor/ArcelorMittal is an exception in the field of structural materials. Businesses focusing on rare, scarce or critical elements are keenly aware of MFA and have been using it to explore availability of resources and discuss the need for a stronger involvement in the circular economy (recovery and recycling), cf. for example UMICORE [19]. This a somewhat restrictive way of using MFA compared to the broad scope of concepts developed by academia and the involvement is usually one-shot, i.e. commissioning a study or hiring a 
Table 2. Strengths and weaknesses of MFA.

\begin{tabular}{lll}
\hline & Strengths & Weaknesses \\
\hline Time, temporality & $\begin{array}{l}\text { Foresight, the future based on modeling } \\
\text { derived from MFA (like IoS models). Deals }\end{array}$ & $\begin{array}{l}\text { The IoS model is a phenomenological model, } \\
\text { also with the past (time series since }\end{array}$ \\
$\begin{array}{ll}\text { beginning/middle of } 20^{\text {th }} \text { century) due to } \\
\text { the long lifetimes of some goods (e.g. }\end{array}$ & based on outside scientific disciplines.
\end{tabular}
construction, machines, industrial equipment).

Scale, space

Scope

Access to data

Standardization

Achievements

Missing elements
Large systems, institutions, large companies or industry associations

$1 / 3$ of the Mendeleev table already covered.
Somewhere in the datasphere but (for a long time) kept safely inside the knowledge base of a research team. Supplementary materials and open data policies are slowly removing this habit.

No

Foresight studies on future materials need, construction, etc.
Too large for most companies. They consider that it is not "their business"!

Missing elements and materials, such as polymers, composites, missing goods and parts. Focus on "pure" elements is also a weakness. Need to take co-elements into account such as alloying/tramp elements in metals, impurities in ores (true at mining, use and recycling levels)

No commercially or publicly available database, except for $\mathrm{MFA}_{\mathrm{c}}$. Therefore, newcomers have a high barrier of entry. Moreover, data reconciliation remains a rather "hidden", "hush-hush" reality.

No

Not enough estimates of recycling rates nor of stocks (anthropogenic mines, hibernating stock, etc.)

Social dimension

Reuse, lean and frugal design rarely studied Economics (MFC, similar to LCC?)

MFA at a smaller scale, e.g. addressing industrial symbiosis

Integration of MFA as a strategic management tool inside business outfits

Evolutions? Automatic creation of MFAs, based on algorithms, automatic collection of data in the Big Data sphere, Artificial Intelligence, etc.

$\mathrm{PhD}$ with that background but not developing an internal lab to keep the competence active and alive in-house;

- industry associations, particularly in the non-ferrous metals and aluminum sectors have been active in commissioning industry-wide MFA studies. Interestingly, the steel sector has kept out of the trend (EUROFER and worldsteel), except in Japan. Their goals were to create a narrative about the future, mainly for communication purposes vs. institutions like the EC, for example: long-term strategic plans are formulated elsewhere, inside companies. Other disciplines are in competition with MFA, especially foresight economics (P. Criqui, in France [20]) but also the large high-level consultants such as McKinsey, BCG, etc.;

- academic research is driven by the research teams themselves but also by the institutions that provide funding and develop program calls in which MFA could be fitted. Among international institutions the UN has been proactive (International Resource Panel [21] and Global Materials Flow Resource Panel) as well as the EC in its programs devoted to raw materials (EIT Raw Materials and EIP Raw Materials) plus the H2020 calls [22]), although MFA is not very explicitly mentioned, 
the focus being mostly on critical raw materials. The IEA, which has been switching attention from energy to raw materials resources, has not yet adopted MFA as a "pet" methodology - their culture being economics. Governments are also focusing more on $\mathrm{MFA}_{\mathrm{c}}$ than on traditional MFA [23]. Note also the focus on waste, pioneered by the Vienna school of MFA (Professor Paul Brunner).

\section{Strengths and weaknesses of MFA}

This section summarizes the comments already expressed in the previous sections (Tab. 2). It is not a criticism of the field of MFA but rather a collection of suggestions for it to move forward and further.

\section{Conclusions}

Scientific communities based on methodologies that measure the environmental and social connections of economic activities (LCA, MFA) are well and alive.

MFA is more "confidential" than LCA, although the practical importance of LCA is probably overblown (LCA is oversold).

The economic world is not listening very well to MFA, because MFA pursues its own targets and does not provide some of the answers that industry would need (recycling rates), nor speak its language (products, price, economic value). However, this may also be because industry is often short-sighted when looking at the future or because the executives who do look at the future are not fully aware of MFA, nor are their high-level consultants.

I do not have any magic wand to remove this difficulty, apart from preaching, working, publishing, lecturing, on and on...

However, MFA is a good idea, it should prevail, eventually!

\section{List of acronyms}

$\begin{array}{ll}\text { ACV } & \text { Analyse de cycle de vie (French) } \\ \text { AFM } & \text { Analyse de flux de matière } \\ \text { BCG } & \text { Boston Consulting Group } \\ \text { CdF } & \text { Cycle du fer (French) } \\ \text { EAF } & \text { Electric Arc Furnace } \\ \text { EFA } & \text { Energy Flow Analysis } \\ \text { EFA } & \text { Element Flow Analysis } \\ \text { EIP } & \text { Raw materials The European Innovation } \\ & \text { Partnership (EIP) on raw materials } \\ \text { EIT } & \text { Raw Materials European Institute \& Inno- } \\ & \text { vation and Technology on Raw Materials } \\ \text { EPLCA } & \text { European Platform on Life Cycle Assess- } \\ & \text { ment } \\ \text { EU } & \text { European Union } \\ \text { ExFA } & \text { Exergy Flow Analysis } \\ \text { GDP } & \text { Gross Domestic Product } \\ \text { GHG } & \text { Greenhouse gases } \\ \text { IEA } & \text { International Energy Agency }\end{array}$

IoF

IoF

ISIE

ISO

LCA

$\mathrm{LCC}$

$\mathrm{LiU}$

MFA

MFAc

MFC

RR

SAM

SETAC

SFA

SFI

SOVAMAT

SSH

STEM

TMR
Intensity of Stock

Intensity of Flow

International Society of Industrial ecology

International Standard Organization

Life-Cycle Analysis

Liffe-Cycle Costing

Life-in-Use

Materials Flow Analysis

Materials Flow Accounting

Materials Flow Costing

Recycling Rate

Society \& Materials (conference)

Society of Environmental Toxicology and Chemistry

Substance Flow Analysis

Sentre for Forskningsdrevet Innovasjon (Norwegian)

SOcial VAlue of MATerials

Social Sciences and Humanities

Science, Technology, Engineering \& Mathematics

Total Materials Requirement

Acknowledgements. Thanks to Jean-Sébastien Thomas, who picked up the responsibility for Sustainability at AM Research after I retired, but who passed away since [24], and to Gaël Fick of IRT-M2P, who has been very active in developing an MFA program within IRT-M.

\section{References}

1. SFI Metal Production Spring Meeting, Trondheim, 24-25 April 2019

2. J.-P. Birat, 2015 Chapter 7 - History, geography and geopolitics of materials, in: Sustainable Materials ScienceEnvironmental Metallurgy, Volume 2 - Pollution and emissions, biodiversity, toxicology and ecotoxicology, economics and social roles, foresight, EDP Sciences, 2021, 630 p. (to be published in 2021)

3. 日本鉄源協会, Nihon Tetsugen Kyokai, Japan, http://www. tetsugen.gol.com/.

4. Usinor, unpublished work, ca. 1992

5. J.-P. Birat, A. Zaoui, Le "Cycle du Fer" ou le recyclage durable de l'acier, La Revue de Métallurgie-CIT 795-807 (2002)

6. J.-P. Birat, First attempts at structuring MFA in the 1990s at USINOR (ArcelorMittal) in the "Cycle of Iron" project, in: Séminaire IRT-M2P, Metz, 28 September 2016

7. J.-P. Birat, Early attempts at developing an MFA for steel, SAM-11, Trondheim, 15-16 May, 2017

8. J.-P. Birat, The Greening of the Steel Industry, Gordon Research Conference, Industrial Ecology, Transforming The use of energy, materials, water and wastes, Colby-Sawyer College, New London, NH, Faye Duchin (chair), August 17-22, 2008

9. F. Hartog, L'occident aux prises avec le temps, nrf. Gallimard, 2020, 344 p.

10. F. Saunier, J.-P. Birat, A. Levasseur, R. Samson, Development of a dynamic inventory for prospective LCA, SAM-6, in: 6th International Conference on Society and Materials, Leuven, 30-31 May 2012 
11. J.-P. Birat, Life Cycle Assessment (LCA) and related methodologies, part of chapter XII, in: S. Seetharaman (Ed.), Treatise on process metallurgy, Elsevier, 2013, 25 p.

12. https://eplca.jrc.ec.europa.eu (Accessed on 28/01/2021)

13. https://is4ie.org (Accessed on 28/01/2021)

14. S. Murakami, M. Oguchi, T. Tasaki, I. Daigo, S. Hashimoto, Lifespan of Commodities, Part I, The creation of a database and its review, JIE (2010)

15. J.-P. Birat, A. Declich, S. Belboom, G. Fick, J.-S. Thomas, M. Chiappini, Society and Materials, a series of regular seminars based on a dialogue between soft and hard sciences, Metallurgical Research \& Technology 112, 501, (2015) doi: $10.1051 / \mathrm{metal} / 2015024$

16. J.-P. Birat, G. Fick, How can social sciences and materials science work together? 12 years of experience with SAM conferences, MRS conference, Boston, November 2018

17. J-S. Thomas, A. Carvallo, J.P. Birat, Metrics for the sustainability value of steel, Matériaux \& Techniques 102, 505 (2014)
18. W.Q. Chen, T.E. Graedel, Anthropogenic cycles of the elements: a critical review, Environmental Science \& Technology 46, 8574-8586 (2012)

19. https://www.umicore.com (Accessed on 28/01/2021)

20. J.-P. Birat, P. Criqui, J.C. Hourcade, Vers une plateforme de prospective, énergie/systèmes techniques et institutions, in: Colloque du Programme Energie (PIE) du CNRS, Nantes, 16-18 Nov. 2009

21. http://www.resourcepanel.org (Accessed on 28/01/2021)

22. https://ec.europa.eu/programmes/horizon2020/en/area/ raw-materials (Accessed on 28/01/2021)

23. Matières mobilisées par l'économie française - Comptes de flux pour une gestion durable des ressources, Études \& documents, $\mathrm{N}^{\circ} 6$ juin 2009, Commissariat général au développement durable, France

24. J-P. Birat, In memoriam, À la mémoire de Jean-Sébastien Thomas (1968-2014), Matériaux et Techniques, 102, N13 (2014)

Cite this article as: Jean-Pierre Birat, MFA vs. LCA, particularly as environment management methods in industry: an opinion, Matériaux \& Techniques 108, 503 (2020) 